\title{
AN INVESTIGATION OF PRUSSIAN BLUE ANALOGUES BY MÖSSBAUER SPECTROSCOPY AND MAGNETIC SUSCEPTIBILITY
}

\author{
PAUL G. RASMUSSEN* and E. A. MEYERS \\ The University of Michigan, Department of Chemistry, Ann Arbor, MI 48109, U.S.A.
}

(Received 17 May 1983; accepted 25 July 1983)

\begin{abstract}
The Mössbauer spectra and magnetic susceptibilities have been obtained for a series of Prussian Blue analogues of general formula $\mathrm{M}_{j}^{\mathrm{A}}\left[\mathrm{M}^{\mathrm{B}}(\mathrm{CN})_{6}\right]_{k} \cdot \mathrm{mH}_{2} \mathrm{O}$ where $\mathrm{M}^{\mathrm{A}}$ and $\mathbf{M}^{\mathrm{B}}$ are transition metal ions, $j$ and $k$ vary with the oxidation states of $\mathbf{M}^{\mathrm{A}}$ and $\mathbf{M}^{\mathrm{B}}$ and $m$ typically has values from 8 to 14 . The compounds were prepared from the hexacyano acids or with large quaternary ammonium counterions and are therefore not contaminated with alkali cations. In each analogue, $\mathrm{A}$ or $\mathrm{B}$ is iron and the second metal is $\mathrm{Mn}, \mathrm{Cu}, \mathrm{Co}$, $\mathrm{Cr}$ or $\mathrm{Ru}$. In each case it was possible to assign the site (A or B), oxidation state and spin state to each transition metal ion. This group of compounds are all class II mixed valence species from their colours, but do not show evidence of linkage isomerism or redox changes compared to the starting materials. The Mössbauer linewidths are consistent with the Ludi model of Prussian Blue.
\end{abstract}

The structure of Prussian Blue, $\mathrm{Fe}_{4}\left[\mathrm{Fe}(\mathrm{CN})_{6}\right]_{3}$ $\times \mathrm{H}_{2} \mathrm{O}$, prototype of a series of polymeric cyanides, has been the object of intensive investigations. ${ }^{1}$ Historically, it was the first documented synthetic coordination complex and its unexpected deep blue colour has triggered many investigations. Many of these studies have attempted to discern whether there were discrete oxidation states or valence equivalency for the structurally different iron atoms. The bulk of information accumulated by X-ray diffraction, ${ }^{2-4}$ infrared spectroscopy, ${ }^{5,6}$ magnetic susceptibility, ${ }^{5,7,8}$ electronic structure, ${ }^{9}$ Mössbauer studies, ${ }^{10-16}$ photoelectron spectroscopy, ${ }^{17,18}$ and neutron diffraction studies ${ }^{19}$ support the assignment of discrete oxidation states as

\section{$\mathrm{Fe}(\mathrm{II})-\mathrm{C} \equiv \mathrm{N}-\mathrm{Fe}^{3+20}$}

an $\mathrm{Fe}^{3+}$ salt of the hexacyanoferrate(II) ion.

Prussian Blue and its many analogues are generally obtained as fine powders. A wide variety of colours, stoichiometries, oxidation states and electronic properties are obtained by substituting different transition metals for the iron atoms in

\footnotetext{
*Author to whom correspondence should be addressed.
}

POLY Vol. 3, No. 2-D
Prussian Blue. This series of polymeric cyanides has the general formula

$$
\mathbf{M}_{j}^{\mathrm{A}}\left[\mathrm{M}^{\mathrm{B}}(\mathrm{CN})_{6}\right]_{k} \cdot \mathrm{mH}_{2} \mathrm{O}
$$

where $\mathbf{M}^{\mathrm{A}}$ and $\mathbf{M}^{\mathrm{B}}$ represent transition metal ions, $j$ and $k$ are the stoichiometric numbers of the compound and vary with the oxidation states of the metals, $A$ and $B$. These compounds are heavily hydrated; so that $m$ typically has a value of 8-14.

The basic features of the crystal structure for Prussian Blue and the analogues were described in the pioneering work by Keggin and Miles ${ }^{2}$ who defined the unit cell as f.c.c. with a cell edge of about $10 \AA$. In their model, position $4 a(0,0,0)$ and $4 b(1 / 2,1 / 2,1 / 2)$ are occupied by $M^{A}$ and $M^{B}$, respectively. The carbon and the nitrogen of the cyanide ligand are located on the two sets of the 24-fold position $(x, 0,0)$. The eight fold positions $(1 / 4,1 / 4,1 / 4)$ and $(3 / 4,3 / 4,3 / 4)$ are randomly occupied by $\mathbf{M}^{\mathrm{A}}$ or alkali metals as required for electroneutrality. All $\mathbf{M}^{\mathrm{B}}$ atoms are octahedrally coordinated to the carbon end of the cyanide (i.e. $M^{B} C_{6}$ ), and the $M^{A}$ atoms are either present as octahedrally coordinated to the nitrogen (i.e. $\mathbf{M}^{\mathrm{A}} \mathbf{N}_{6}$ ) or as uncoordinated interstitial ions. In this model, water molecules do not occupy crystalline sites, but rather are present only as zeolitic or surface water. 
The model proposed by Ludi et al..$^{21}$ retains some of the features of that of Keggin and Miles. Much of the new model is described in the context of the space group $(F m 3 m)$, with a cell edge ranging between 9.9 and $10.9 \AA$. The exact cell edge is a function of the specific compound and the differences reflect the $M^{B}-C$ and the $M^{A}-N$ bond distances. Their discovery of primitive reflections from single crystals of Prussian Blue changes the space group to $P m 3 m$. The $\mathbf{M}^{\mathrm{A}}$ and the $\mathbf{M}^{\mathrm{B}}$ atoms occupy the four-fold positions exclusively, and are, therefore, octahedrally coordinated to the nitrogen and the carbon atoms, respectively. The assumption of randomly distributed $\mathbf{M}^{\mathrm{A}}$ atoms in uncoordinated interstitial sites $(8 c)$ is discarded. The occupancy rate of the sites $4 a$ and $4 b$ is a function of the stoichiometry of the analogue. For example, when $j=1$ and $k=1$, then there will be a $100 \%$ occupancy of both sites $4 a$ and $4 b$. However, when the $j: k$ ratio is greater than 1 , the occupancy of site $4 a$ remains at $100 \%$, while that for site $4 b$ becomes less than $100 \%$. Specifically, when the $j: k$ ratio is $4: 3$, as is the case for Prussian Blue, the average composition is postulated to be $\mathrm{M}^{\mathrm{B}} \mathrm{C}_{6}$ and $\mathrm{M}^{\mathrm{A}} \mathrm{N}_{4.5} \mathrm{O}_{1.5}$. The absence of whole $\mathrm{M}^{\mathrm{B}}(\mathrm{CN})_{6}$ octahedra leads to interruptions in the very tight three dimensional $\mathbf{M}^{\mathrm{A}}-\mathbf{N C}-\mathbf{M}^{\mathrm{B}}-\mathrm{CN}-\mathbf{M}^{\mathrm{A}}$ lattice postulated by Keggin and Miles. Coordinated water in sites normally occupied by the nitrogens has been suggested to explain the infrared spectra of the analogues. ${ }^{22,23}$ As the ratio of $j: k$ increases, the differences between the two models becomes more pronounced because as $j: k$ increases the density should decrease for the Ludi model and increase for that by Keggin and Miles.

The problem in differentiating between the two models on the basis of density measurements is, that such measurements are also a reflection of the chemical composition. If there are any unspecified alkali metals or water molecules in the compound under study, then the density measurements can be misleading. In the past, very little specific analytical data was ever included with the results, and it is likely that a variety of analytically different compounds were synthesized and studied as Prussian Blue. The structural implications of the two models and the relationship of the non-cubic analogues is reviewed elsewhere. ${ }^{24}$

We have carried out a systematic study of a series of Prussian Blue analogues. In each, at least one of the metal atoms (and in the case of Prussian Blue-both) is iron. One objective of this investigation was to determine whether or not linkage isomerism 'and/or oxidation-reduction occurs for the analogs by determining the site configuration and spin state for metal ions.
In the preparation of the compound which has been called "Turnbull's blue" but which is actually Prussian Blue, it is clear that linkage isomerism or oxidation-reduction has occurred. ${ }^{25}$ Underlying the study of the analogs is the question of whether this linkage isomerism is typical or even common. Note that while linkage isomerism is indistinguishable from oxidation-reduction in Prussian Blue, this is not the case when $\mathbf{M}^{A}$ is a different atom from $\mathbf{M}^{\mathbf{B}}$.

\section{EXPERIMENTAL SECTION}

Prussian Blue analogues were kindly supplied from the laboratory of Dr. A. Ludi, Universität Bern, Bern, Switzerland. These compounds were prepared with careful attention to analytical composition as described by Buser. ${ }^{26}$ The preparations avoid contamination by alkali cations by using the acid form of the hexacyano species, or by using large quaternary ammonium counterions.

\section{Magnetic susceptibilities}

Magnetic susceptibilities were measured by the Faraday method. Samples (about $15 \mathrm{mg}$ ) in an open quartz bucket were suspended from a R-100 Cahn Electrobalance into a V-3400 Varian electromagnet fitted with Heyding pole pieces. A Varian Fieldial Mark I was used to regulate the field strength. Susceptibilities were corrected for diamagnetic contributions using values listed by Figgis and Lewis. ${ }^{27}$ The system was checked by calibration with $\mathrm{Ni}\left(\mathrm{NH}_{4}\right)_{2}\left(\mathrm{SO}_{4}\right)_{2}, 6 \mathrm{H}_{2} \mathrm{O}$ against $\mathrm{HgCo}(\mathrm{SCN})_{4}$. Results corresponded closely to those reported by Simmons. ${ }^{28}$ The magnetic data is summarized in Table 2.

The Mössbauer spectra were obtained using a constant accelcration drive unit coupled with a multichannel analyzer operated in the time mode. In the temperature range $84^{\circ}<T<298 \mathrm{~K}$, the spectrometer employed was built by T. M. Gould and has been described in detail in his thesis. ${ }^{29}$ For this temperature range, a styrofoam insulated dewar was used; the temperature was monitored with a $\mathrm{Cu}$ constantin thermocouple. All reported Mössbauer spectra were gathered with temperature variations of less than $\pm 2 \%{ }^{\circ} \mathrm{C}$. A very thin piece of circular carboard was cut to a diameter of $3.5 \mathrm{~cm}$ with an inner hole of diameter $2.7 \mathrm{~cm}$. One side was covered with mylar film attached with double sided tape. A finely ground powder $(40-90 \mathrm{mg})$ as then pressed into the hole and covered with a second piece of mylar. These samples were fitted into the aluminum block of the cryostat.

An enriched ${ }^{57} \mathrm{Fe}$ sample was used to calibrate the velocity. All chemical shifts (cs) are relative to 
sodium nitroprusside ( $T=$ ambient). The source temperature remained at room temperature for all spectra obtained with this system.

A second system was used to obtain the spectra in the temperature range $4.2 \mathrm{~K}<T<77 \mathrm{~K}$. ${ }^{30}$ Samples $(30-50 \mathrm{mg})$ were pressed in small plastic vials $(1 \mathrm{~cm}$ dia.) and stoppered with styrofoam. Velocities were internally calibrated. The CS are relative to sodium nitroprusside. Since the source is immersed in the dewar, the source temperature was monitored and maintained at $18 \mathrm{~K}$. No corrections were made for the variance in source temperature between the two systems.

The Mössbauer data points were fitted to a series of Lorentzian or Gaussian-distribution of Lorentzian shaped peaks by a nonlinear least squares analysis. The non-resonant background is fit to a parabola. The method used to fine the parameters which minimize the chi-squared value is the Gauss-Newton iteration method. Specific details (including a listing of the main program and the subroutines) are given in Gould's thesis. ${ }^{29}$

The print-out for this program includes the normalized chi-squared $\left(\chi^{2}\right)$ value after each iteration and after the final calculation, a list of the best fitting parameters, with a measured fitting error, experimental vs the fitted area, individual line and/or pair areas and estimated diagonalized areas. The goodness of fit parameter $\chi^{2}$ was compared for various initial conditions, e.g. one line 2 independent lines, QS pair, etc. An acceptable value of $\chi^{2}$ was $0.95 \leq \chi^{2} \leq 1.25$. Two independent lines were considered a QS pair if the areas were within $5 \%$ of each other and if the $\chi^{2}$ did not radically change constraining the data to fit a QS pair. A typical spectrum is shown in Fig. 1. In all spectra, over one million counts per channel were accumulated.

Guinier X-ray photographs were obtained for samples where the number of phases was in doubt.

\section{RESULTS AND DISCUSSION}

The results are divided into two parts: the first deals with iron atoms expected to be in $M^{\mathrm{B}} \mathrm{C}_{6}$ sites; the second deals with iron atoms expected to be bonded to the nitrogen end of the cyanide $\left(\mathrm{M}^{\mathrm{A}}\right)$. The discussion will be directed towards confirming the oxidation and spin state, and elucidating insofar as possible the site symmetry.

Room temperature Mössbauer spectra obtained for $\mathrm{K}_{3}\left[\mathrm{Fe}(\mathrm{CN})_{6}\right]$ and $\mathrm{K}_{4}\left[\mathrm{Fe}(\mathrm{CN})_{6}\right]$ are used as references for line width (FWHM), position (CS) relative to sodium nitroprusside, and quadrupole splitting (QS) for this series of compounds. For $\mathrm{K}_{3}\left[\mathrm{Fe}(\mathrm{CN})_{6}\right] \cdot 3 \mathrm{H}_{2} \mathrm{O}$ the values are $\mathrm{CS}=\mathbf{0 . 1 3 6}$ $\pm 0.007 \mathrm{~mm} / \mathrm{sec} ; \quad Q S=0.269 \pm 0.008 \mathrm{~mm} / \mathrm{sec}$; $\mathrm{FWHM}=0.365 \pm 0.008 \mathrm{~mm} / \mathrm{sec}$, in close agreement with the results published by Garg and Goel. ${ }^{31} \mathrm{~K}_{4}\left[\mathrm{Fe}(\mathrm{CN})_{6}\right] \cdot 2 \mathrm{H}_{2} \mathrm{O}$, our experimental parameters are: $\mathrm{CS}=0.234 \pm 0.005 \mathrm{~mm} / \mathrm{sec} ; \mathrm{QS}=$ $0.0 \mathrm{~mm} / \mathrm{sec} ; \quad F W H M=0.324 \pm 0.06 \mathrm{~mm} / \mathrm{sec}$. in good agreement with Hall et al. ${ }^{32}$ Note that there is little difference in CS between the $\mathrm{Fe}$ (II) and Fe(III) cyanide complexes. Differentiation between $\mathrm{Fe}$ (II), and $\mathrm{Fe}$ (III) cyanide complexes is based on the presence/absence of temperature-dependent QS.

\section{Compound: $\mathrm{Co}_{3}\left[\mathrm{Fe}(\mathrm{CN})_{6}\right]_{2} \cdot 14 \mathrm{H}_{2} \mathrm{O}$}

The compound $\mathrm{Co}_{3}\left[\mathrm{Fe}(\mathrm{CN})_{6}\right]_{2} \cdot 14 \mathrm{H}_{2} \mathrm{O}$ is a deep

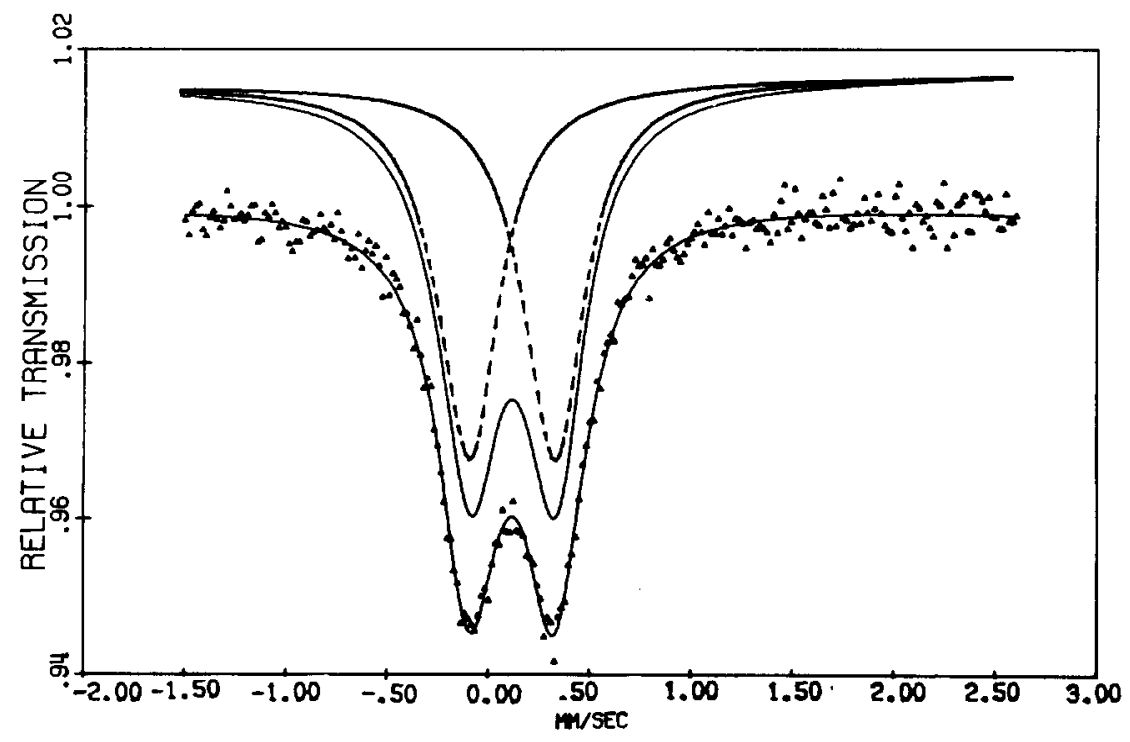

Fig. 1. Mössbauer spectrum of $\mathrm{Co}_{3}\left[\mathrm{Fe}(\mathrm{CN})_{6}\right]_{2} \cdot 14 \mathrm{H}_{2} \mathrm{O}$ at $298 \mathrm{~K}$. 
red-brown with a well defined crystaline phase. ${ }^{24}$ The magnitude of the CS is that expected for low spin iron. The QS is temperature dependent (Table 1). The temperature dependent spectra were fitted by the usual techniques described elsewhere. ${ }^{29}$ The size of the QS and the extent of variation with temperature clearly indicate low spin Fe(III) behaviour and suggest a splitting with the $t_{2 g}$ octahedral orbitals of the order of $k T\left(\sim 170 \mathrm{~cm}^{-1}\right)$.

The magnetic susceptibility is given in Table 2 . Since both $\mathrm{Co}$ (II) and $\mathrm{Fe}$ (III) are contributing to the paramagnetism of the compound, attribution of the magnetism to the two species can only be approximate. Assuming no interaction, the form for the magnetic moment of an $A_{n} B_{m}$ salt is ${ }^{33}$

$$
\mu_{\mathrm{AB}}=\left[n \mu_{\mathrm{A}}^{2}+m \mu_{\mathrm{B}}^{2}\right]^{1 / 2} .
$$

Using spin only values for $\mathrm{Co}$ (II), $\mathrm{Fe}$ (III), one calculates a room temperature moment of $\mu_{\mathrm{AB}}=6.7$. However, substantial contribution to the observed or orbital contribution from both species is likely. If one takes accepted values ${ }^{27}$ of $\mu=2.4$ for $\mathrm{K}_{3} \mathrm{Fe}(\mathrm{CN})_{6}$ and $\mu=5.1$ for $\left(\mathrm{NH}_{4}\right)_{2} \mathrm{Co}\left(\left(\mathrm{SO}_{4}\right)_{2} \cdot 6 \mathrm{H}_{2} \mathrm{O}\right.$ and uses the formula above, one calculates $\mu=9.46$. The observed value of $\mu=7.8$ falls reasonably between these values. Thus the Mössbauer and magnetic susceptibility data confirm the assignment $\mathrm{Co}$ (II)- $\mathrm{N} \equiv \mathrm{C}-\mathrm{Fe}$ (III). Interestingly, this compound does not undergo transformation at room temperature to $\mathrm{Fe}_{3}\left[\mathrm{Co}(\mathrm{CN})_{6}\right] \cdot 14 \mathrm{H}_{2} \mathrm{O}$ whose parameters are given below.

\section{Compound: $\mathrm{Na}_{3}\left[\mathrm{Fe}(\mathrm{CN})_{s}\right.$ pyrazine $] \cdot 3 \mathrm{H}_{2} \mathrm{O}$}

The compound $\mathrm{Na}_{3}\left[\mathrm{Fe}(\mathrm{CN})_{5}\right.$ pyrazine $] \cdot 3 \mathrm{H}_{2} \mathrm{O}$ is bright red. The Mössbauer data, in the temperature range $83 \leq T \leq 294 \mathrm{~K}$, give a wellresolved doublet.

The QS is independent of temperature and is apparently due to the difference in covalency between the pyrazine and cyanide ligands. The data agree closely with that reported by Weihofen ${ }^{34}$ for the pyrrolidine-substituted complex.

The compound is diamagnetic which, coupled with the Mössbauer data prescribes a $\mathrm{Fe}(\mathrm{II}) \mathrm{C}_{5} \mathrm{~N}_{1}$ site configuration. Although this compound is not a Prussian Blue analogue, the data are useful for comparison purposes to other low spin iron(II) cyanides. In particular, they show the sensitivity of the quadrupole splitting of low spin iron(II) to lowered symmetry.

Table 1. Mössbauer data

\begin{tabular}{|c|c|c|c|c|}
\hline & $\begin{array}{l}\text { Temp } \\
\mathrm{K}+28\end{array}$ & Cs, $\mathrm{mm} / \mathrm{sec}$ & $\mathrm{QS}, \mathrm{mm} / \mathrm{sec}$ & FWHM, $\mathrm{mm} / \mathrm{sec}$ \\
\hline $\mathrm{Co}_{3}\left[\mathrm{Fe}(\mathrm{CN})_{6}\right]_{2} \cdot 14 \mathrm{H}_{2} \mathrm{O}$ & $\begin{array}{r}298.0 \\
294.2 \\
153.8 \\
113.6 \\
88.4 \\
84.7 \\
\star 77.0 \\
\$ 60.0 \\
\star 40.0 \\
* 18.0\end{array}$ & $\begin{array}{l}0.115 \pm 0.004 \\
0.116 \mp 0.002 \\
0.142 \mp 0.003 \\
0.153 \mp 0.006 \\
0.182 \mp 0.007 \\
0.184 \mp 0.005 \\
0.049 \mp 0.009 \\
0.056 \mp 0.003 \\
0.056 \mp 0.005 \\
0.056 \mp 0.005\end{array}$ & $\begin{array}{l}0.422 \pm 0.004 \\
0.426 \mp 0.010 \\
0.738 \mp 0.006 \\
0.828 \mp 0.010 \\
0.877 \mp 0.009 \\
0.884 \mp 0.011 \\
0.894 \mp 0.010 \\
0.910 \mp 0.009 \\
0.917 \mp 0.004 \\
0.950 \mp 0.006\end{array}$ & 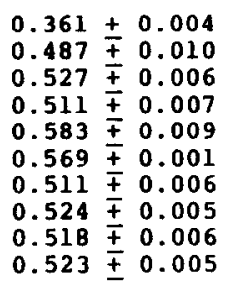 \\
\hline \multicolumn{5}{|c|}{ *source temperature: $5-10 \mathrm{~K}$. } \\
\hline $\mathrm{Na}_{3}\left[\mathrm{Fe}(\mathrm{CN}){ }_{6} \mathrm{PYz} \cdot 3_{2} \mathrm{O}\right.$ & $\begin{array}{r}294.0 \\
84.0\end{array}$ & $\begin{array}{l}0.283 \pm 0.002 \\
0.362 \pm 0.003\end{array}$ & $\begin{array}{l}0.749 \pm 0.008 \\
0.758 \pm 0.006\end{array}$ & $\begin{array}{l}0.484 \pm 0.007 \\
0.427 \pm 0.005\end{array}$ \\
\hline $\mathrm{Mn}_{2}\left[\mathrm{Fe}(\mathrm{CN}){ }_{6}\right] \cdot 8 \mathrm{H}_{2} \mathrm{O}$ & $\begin{array}{r}294.0 \\
84.2\end{array}$ & $\begin{array}{l}0.164 \pm 0.002 \\
0.252 \pm 0.003\end{array}$ & -- & $\begin{array}{l}0.498 \pm 0.007 \\
0.536 \pm 0.006\end{array}$ \\
\hline $\mathrm{Cu}_{2}\left[\mathrm{Fe}(\mathrm{CN})_{6}\right] \cdot 14 \mathrm{H}_{2} \mathrm{O}$ & $\begin{array}{r}297.0 \\
87.0\end{array}$ & $\begin{array}{l}0.168 \pm 0.002 \\
0.219 \pm 0.003\end{array}$ & -- & $\begin{array}{l}0.401 \pm 0.006 \\
0.420 \pm 0.005\end{array}$ \\
\hline $\mathrm{Co}_{2}\left[\mathrm{Fe}(\mathrm{CN})_{6}\right] \cdot 8 \mathrm{H}_{2} \mathrm{O}$ & $\begin{array}{rl}298.0 & K \\
87.4 & K\end{array}$ & $\begin{array}{l}0.150 \pm 0.006 \\
0.240 \pm 0.009\end{array}$ & $\begin{array}{l}-- \\
--\end{array}$ & $\begin{array}{l}0.426 \pm 0.006 \\
0.498 \pm 0.009\end{array}$ \\
\hline $\mathrm{Co}_{2}\left[\mathrm{Fe}(\mathrm{CN})_{6}\right] \cdot 9 \mathrm{H}_{2} \mathrm{O}$ & $\begin{aligned} 298.0 \mathrm{~K} \\
87.2 \mathrm{~K}\end{aligned}$ & $\begin{array}{l}0.148 \pm 0.009 \\
0.228 \pm 0.006\end{array}$ & -- & $\begin{array}{l}0.487 \pm 0.004 \\
0.568 \pm 0.003\end{array}$ \\
\hline
\end{tabular}


Table 1 (Contd)

\begin{tabular}{|c|c|c|c|c|}
\hline & $\operatorname{Temp}_{K \pm 28}$ & Cs, $\mathrm{mm} / \mathrm{sec}$ & QS, mm/sec & FWHM, $\mathrm{mm} / \mathrm{sec}$ \\
\hline $\mathrm{Cr}_{4}\left[\mathrm{Pe}(\mathrm{CN})_{6}\right]_{3} \cdot 14 \mathrm{H}_{2} \mathrm{O}$ & $\begin{array}{r}298.0 \\
87.4 \\
4.3\end{array}$ & $\begin{array}{l}0.155 \pm 0.005 \\
0.229 \pm 0.004 \\
0.261 \pm 0.006\end{array}$ & $\begin{array}{l}-- \\
--\end{array}$ & $\begin{array}{l}0.578 \pm 0.004 \\
0.580 \pm 0.007 \\
0.590 \pm 0.007\end{array}$ \\
\hline $\mathrm{Pe}_{3}\left[\mathrm{CO}(\mathrm{CN})_{6}\right]_{2} \cdot 14 \mathrm{H}_{2} \mathrm{O}$ & $\begin{array}{r}298.0 \\
282.1 \\
187.2 \\
134.2 \\
99.5 \\
87.8 \\
84.2 \\
40.0 \\
4.2\end{array}$ & 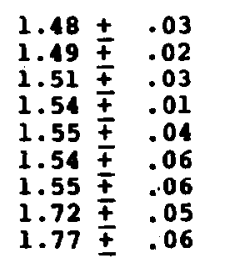 & 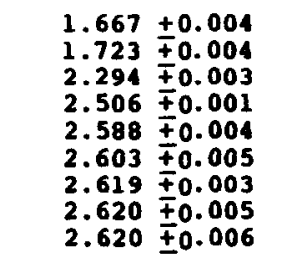 & 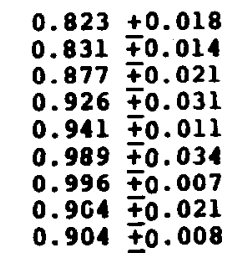 \\
\hline $\mathrm{Fe}_{4}\left[\mathrm{Ru}(\mathrm{CN})_{6}\right]_{3} \cdot 14 \mathrm{H}_{2} \mathrm{O}$ & $\begin{array}{r}298.0 \\
273.0 \\
87.0 \\
84.0 \\
5.0\end{array}$ & $\begin{array}{l}0.617 \pm 0.002 \\
0.643 \pm 0.002 \\
0.751 \pm 0.003 \\
0.801 \pm \\
0.807 \pm 0.004 \\
\mp \\
0.004\end{array}$ & $\begin{array}{l}0.628 \pm 0.004 \\
0.617 \pm 0.006 \\
0.676 \pm 0.004 \\
0.715 \pm 0.006 \\
0.692 \pm 0.005\end{array}$ & $\begin{array}{l}0.646 \pm 0.004 \\
0.543 \mp 0.006 \\
0.638 \mp 0.008 \\
0.672 \mp 0.011 \\
0.549 \pm 0.008\end{array}$ \\
\hline \multirow[t]{4}{*}{ Prussian Blue } & 298.0 & $\begin{array}{l}0.669 \pm 0.005 \\
0.109 \pm 0.006\end{array}$ & $0.868 \pm 0.009$ & $\begin{array}{l}0.606 \pm 0.014 \\
0.378 \pm 0.007\end{array}$ \\
\hline & 281.2 & $\begin{array}{l}0.671 \pm 0.006 \\
0.113 \pm 0.002\end{array}$ & $0.613 \pm 0.009$ & $\begin{array}{l}0.577 \pm 0.008 \\
0.403 \pm 0.004\end{array}$ \\
\hline & 87.4 & $\begin{array}{l}0.775 \pm 0.004 \\
0.183 \pm 0.002\end{array}$ & $0.696 \pm 0.006$ & $\begin{array}{l}0.647 \pm 0.006 \\
0.462 \pm 0.005\end{array}$ \\
\hline & 82.4 & $\begin{array}{l}0.764 \pm 0.004 \\
0.159 \pm 0.002\end{array}$ & $0.707 \pm 0.019$ & $\begin{array}{l}0.682 \pm 0.006 \\
0.491 \pm 0.008\end{array}$ \\
\hline
\end{tabular}

Table 2. Magnetic susceptibility data

\begin{tabular}{|c|c|c|}
\hline & $\left(\times 10^{-3}\right) \times_{M}^{\circ}(293 \cdot \mathrm{K})$ & $u_{B M}$ (Curie Law) \\
\hline $\mathrm{CO}_{3}\left(\mathrm{Fe}(\mathrm{CN})_{6} \mathrm{~J}_{2} \cdot 14 \mathrm{E}_{2} \mathrm{O}\right.$ & $23.5 / \mathrm{mole}$ & 7.4 \\
\hline $\mathrm{Mn}_{2}\left(\mathrm{~F} \bullet(\mathrm{CN})_{6}\right) \cdot 8 \mathrm{H}_{2} \mathrm{O}$ & $15.4 / \mathrm{Mn}$ & 6.0 \\
\hline $\mathrm{Cu}_{2}\left[\mathrm{Fe}(\mathrm{cs})_{6}\right] \cdot 14 \mathrm{~B}_{2} \mathrm{O}$ & $1.9 / \mathrm{Cu}$ & 2.1 \\
\hline $\mathrm{CO}_{2}\left[\mathrm{P} \bullet(\mathrm{Cl})_{6}\right] \cdot 8 \mathrm{H}_{2} \mathrm{O}$ & $11.2 / \mathrm{Co}$ & 5.2 \\
\hline $\mathrm{CO}_{2}\left[\mathrm{Fe}(\mathrm{CN})_{6}\right] \cdot 9 \mathrm{H}_{2} \mathrm{O}$ & $9.2 / \mathrm{Co}$ & 4.6 \\
\hline$C x_{4}\left[F \in(C X)_{6}\right]_{3} \cdot 14 H_{2} O$ & $6.73 / \mathrm{Cr}$ & 3.9 \\
\hline $\mathrm{Fo}_{3}\left[\mathrm{CO}(\mathrm{CN})_{6}\right)_{2} \cdot 14 \mathrm{~B}_{2} \mathrm{O}$ & $14.0 / \mathrm{re}$ & 5.7 \\
\hline$F 0_{4}\left[R u(C N)_{6}\right]_{3} \cdot 14 \mathrm{~B}_{2} \mathrm{O}$ & $15.3 / \mathrm{Fe}$ & 6.0 \\
\hline $\mathrm{Fe}_{4}\left[\mathrm{Fe}(\mathrm{CN})_{6}\right]_{3} \cdot 14 \mathrm{~B}_{2} \mathrm{O}$ & $13.9 / 8$ & 5.7 \\
\hline
\end{tabular}

Compound: $\mathrm{Mn}_{2}\left[\mathrm{Fe}(\mathrm{CN})_{6}\right] \cdot 8 \mathrm{H}_{2} \mathrm{O}$

The compound $\mathrm{Mn}_{2}\left[\mathrm{Fe}(\mathrm{CN})_{6}\right] \cdot 8 \mathrm{H}_{2} \mathrm{O}$ is pale blue. The Mössbauer spectra obtained in the temperature range $294 \geq T \geq 84 \mathrm{~K}$ show a single resonance peak. The magnitude of the CS and the lack of a QS is consistent with a low spin iron(II) and the magnetic susceptibility substantiates a $\mathrm{Mn}(\mathrm{II})$ assignment as the only paramagnetic ion and confirms the configuration, $\mathrm{Fe}(\mathrm{II})-\mathrm{C}=\mathrm{N}-\mathrm{Mn}(\mathrm{II})$. This compound is isostructural to $\mathrm{Mn}_{2}\left[\mathrm{Ru}(\mathrm{CN})_{6}\right] \cdot 8 \mathrm{H}_{2} \mathrm{O}^{35}$ which has non-cubic struc- ture and bridged pairs of manganese ions. Although the iron is not at a cubic site, the Mössbauer parameters indicate an octahedral cyanide site (no discernible quadruple splitting and typical linewidth).

\section{Compound: $\mathrm{Cu}_{2}\left[\mathrm{Fe}(\mathrm{CN})_{6}\right] \cdot 14 \mathrm{H}_{2} \mathrm{O}$}

$\mathrm{Cu}_{2}\left[\mathrm{Fe}(\mathrm{CN})_{6}\right] \cdot 14 \mathrm{H}_{2} \mathrm{O}$ is a brown compound; this colour is caused by strong ultraviolet charge transfer bands tailing off into the blue end of the visible spectrum. ${ }^{36}$ The Mössbauer parameters indicate 
that the iron atom is in an octahedral environment as low spin iron(II). The configuration of $\mathrm{Fe}$ (II) $-\mathrm{C} \equiv \mathbf{N}-\mathrm{Cu}$ (II) is consistent with both the Mössbauer and magnetic susceptibility data.

$$
\begin{aligned}
& \text { Compounds: } \quad \mathrm{Co}_{2}\left[\mathrm{Fe}(\mathrm{CN})_{6}\right] \cdot 8 \mathrm{H}_{2} \mathrm{O} \\
& \mathrm{Co}_{2}\left[\mathrm{Fe}(\mathrm{CN})_{6}\right] \cdot 9 \mathrm{H}_{2} \mathrm{O}
\end{aligned}
$$

and

The compound $\mathrm{Co}_{2}\left[\mathrm{Fe}(\mathrm{CN})_{6}\right] \cdot 8 \mathrm{H}_{2} \mathrm{O}$ is a deep blue-green. The compound $\mathrm{Co}_{2}\left[\mathrm{Fe}(\mathrm{CN})_{6}\right] \cdot 9 \mathrm{H}_{2} \mathrm{O}$ is black. The Mössbauer spectra obtained for both show a single resonance peak, indicating iron atoms in similar sites, defined by: $\mathrm{Fe}(\mathrm{II}) \mathrm{C}_{6}$.

The magnetic moments indicate that in both cases the $\mathrm{Co}^{2+}$ are weak but slightly different fields. Given the importance in the Ludi model of water in the crystal field around the $\mathrm{M}_{\mathrm{A}}$ site, ${ }^{24}$ the addition of one water per mole of compound might strengthen the crystal field enough to result in observable orbital quenching. More definite descriptions of the ligand fields surrounding the $\mathrm{Co}^{2+}$ ions can not be made.

\section{Compound: $\mathrm{Cr}_{4}\left[\mathrm{Fe}(\mathrm{CN})_{6}\right]_{3} \cdot 14 \mathrm{H}_{2} \mathrm{O}$}

The compound $\mathrm{Cr}_{4}\left[\mathrm{Fe}(\mathrm{CN})_{6}\right]_{3} \cdot 14 \mathrm{H}_{2} \mathrm{O}$ is dark green. The Mössbauer spectra obtained in the temperature range $298 \geq T \geq 4.3 \mathrm{~K}$ have a single resonance peak.

The lack of QS and the magnitude of the CS indicate that the site assignment for the iron atom is $\mathrm{Fe}(\mathrm{II}) \mathrm{C}_{6}$. Any observed paramagnetism should be a function of only the chromium atom. The experimentally observed magnetic moment is close to the spin-only value for $\mathrm{Cr}$ (III). The configuration $\mathrm{Fe}(\mathrm{II})-\mathrm{C} \equiv \mathrm{N}-\mathrm{Cr}$ (III) is substantiated by both the experimental measurements.

\section{Iron atoms in $\mathrm{M}^{\mathrm{A}}$ sites}

There remains controversy concerning the positions of the $\mathbf{M}^{\mathrm{A}}$ metal atoms. The two models assign different locations for these atoms. That the stoichiometry will influence the kinds of sites occupied by the $\mathrm{M}^{\mathrm{A}}$ atoms is agreed to by both. In the Keggin model, $\mathbf{M}^{\mathrm{A}}$ atoms are in well-defined nitrogen octahedra and interstitial sites. The number of interstitial sites occupied is a function of the stoichiometry. In the Ludi model, the $\mathbf{M}^{\mathrm{A}}$ atoms are all in six-coordinate sites. No interstitial sites are postulated to be occupied by $\mathbf{M}^{\mathbf{A}}$ atoms. In order to define the $\mathbf{M}^{A}$ site more exactly, Mössbauer and magnetic susceptibilities were obtained.

We have redone the magnetic susceptibility and Mössbauer spectra for Prussian Blue and include it for comparison. The primary motive for repeating earlier work was the paucity of analytical data for compounds labeled as Prussian Blue. The water content has been analytically well-defined in our preparations, whereas in the past, water has been assumed to be zeolitic in nature. The single-crystal work done on Prussian Blue ${ }^{21,37}$ substantiates water occupying crystalline sites.

\section{Compound: $\mathrm{Fe}_{3}\left[\mathrm{Co}(\mathrm{CN})_{6}\right]_{2} \cdot 14 \mathrm{H}_{2} \mathrm{O}$}

The compound $\mathrm{Fe}_{3}\left[\mathrm{Co}(\mathrm{CN})_{6}\right]_{2} \cdot 14 \mathrm{H}_{2} \mathrm{O}$, is green-yellow. From the CS values, it is obvious that this is a high spin ferrous complex. The temperature dependence of the QS suggests a splitting in levels on the order of $340 \mathrm{~cm}^{-1}$ or about double that found for the $\mathrm{Fe}(\mathrm{II}) \mathrm{C}_{6}$ site.

In addition to the $\mathrm{QS}$, the magnitude of the FWHM for this compound is almost twice that obtained for similary prepared samples where the iron atoms is in the $\mathbf{M}^{\mathbf{B}}$ site. If two or more similar iron sites are present, broadened lines would be expected. Two lattice effects can explain this situation: (1) impurities in the sample, that is, the iron atoms are not in the well-defined $\mathbf{M}^{\mathrm{A}}$ sites for a face center cubic crystal, as expected. Or, (2) two nearly equivalent sites exist (i.e. cis/trans orientation of water ligands about the iron atoms). The magnetic data are consistent with a high spin ferrous complex with orbital contribution to the moment. The Guiniér photographs indicate only one phase is present. In this case the evidence parallels the Ludi model quite closely.

\section{Compound: $\mathrm{Fe}_{4}\left[\mathrm{Ru}(\mathrm{CN})_{6}\right]_{3} \cdot 14 \mathrm{H}_{2} \mathrm{O}$}

The compound $\mathrm{Fe}_{4}\left[\mathrm{Ru}(\mathrm{CN})_{6}\right]_{3} \cdot 14 \mathrm{H}_{2} \mathrm{O}$ is dark blue, quite similar to Prussian Blue.

The Mössbauer spectra obtained are rather diffuse at temperatures higher than $87.2 \mathrm{~K}$ and of relatively low intensity. The values obtained for the CS vary strongly with temperature; quite similar to that postulated for other Fe(III) complexes. ${ }^{38}$ The QS varies with temperature in a manner that may be a function of fitting the rather diffuse spectra.

The FWHM is again larger than what is obtained for similarly prepared samples where the iron atoms is in well-defined $\mathbf{M}^{\mathrm{B}}$ site. The FWHM is indicative of two or more lattice sites being occupied by the $\mathrm{Fe}$ (III) $\left(\mathrm{M}^{\mathrm{A}}\right)$. If the sites were extremely different (i.e. interstitial site vs $\mathbf{M}^{\mathrm{A}}$ site) the two sets of doublets would probably be resolvable.

The magnetic data are consistent with the site assignments

$$
\mathrm{Fe}(\mathrm{III})-\mathrm{N} \equiv \mathrm{C}-\mathrm{Ru} \text { (II). }
$$

There is no evidence for linkage isomerism in this species. 


\section{Compound: Prussian Blue $\mathrm{Fe}_{4}\left[\mathrm{Fe}(\mathrm{CN})_{6}\right]_{3} \cdot 14 \mathrm{H}_{2} \mathrm{O}$}

A wide variety of methods have been used to elucidate the structure of Prussian Blue and consequently there exists a large volume of published data. Vide supra.

The Mössbauer spectra obtained in the temperature range: $84<T<298 \mathrm{~K}$ vary rather little. The variation in the CS and QS with temperature is probably a function of the curve fitting process, the overlaps making resolution difficult. The asymmetry on the r.h.s. of the more intense peak indicates that the observed envelope is the sum of two unresolved peaks. An investigation using an ${ }^{56} \mathrm{Fe}$ labeled Prussian Blue ${ }^{39}$ substantiates this type of fitting, where both an $\mathrm{Fe}$ (III) (non-octahedral symmetry) and $\mathrm{Fe}(\mathrm{II})$ (octahedral symmetry) are present, as do our data for the analogues.

Our magnetic moment value is in general agreement with those previously obtained ${ }^{7,8}$ although some of the discrepancies may be due to differences in formulation especially regarding potassium ion or water.

\section{CONCLUSIONS}

In all the cases examined here, the ions bonded to the carbon end of the cyanide $\left(\mathrm{M}^{\mathrm{B}}\right)$ are in low spin configurations, and all ions in $\mathbf{M}^{\mathbf{A}}$ sites are high spin. None of this group is involved in linkage isomerism and the location of the ions has been determined to be that predicted based on the starting materials. All compounds in the group (with the exception of course of $\mathrm{Na}_{3}\left[\mathrm{Fe}(\mathrm{CN})_{s}\right.$ pyz] $\left.\cdot 3 \mathrm{H}_{2} \mathrm{O}\right)$ appear to be Prussian Blue analogues in the sense of having well defined octahedral cyanide sites, extensive water of hydration, and variations in the $\mathbf{M}^{\mathbf{A}}$ sites. This latter property is particularly evident in the Mössbauer linewidths which are substantially greater for ions in $\mathrm{M}^{\mathrm{A}}$ sites, in accord with the Ludi model. In Prussian Blue itself the linewidths are uncertain because of overlapping peaks whereas in the analogs the effect is clear. Conversely, the $\mathbf{M}^{\mathrm{B}}$ linewidths are relatively narrow and no quadrupole splitting is observed for the low spin iron(II) cases. All of these compounds fit the class II description of mixed valency, having colors which are not composites of the constituents. The determination of magnetic ordering at low temperature awaits further investigation.

\section{REFERENCES}

1. B. M. Chadwick and A. G. Sharpe, Adv. Inorg. Chem. Radiochem. 1966, 8, 83.

2. J. F. Keggin and F. D. Miles, Nature, 1936, 137, 577.
3. H. B. Weiser, W. O. Milligan and J. Bates, J. Phys. Chem. 1942, 46, 99.

4. A. Ludi, H. U. Güdel and R. Hugi, Chimia 1969, 23, 194.

5. G. Emschwiller, Compt. Rend. 1954, 238, 1414.

6. R. E. Wilde, S. N. Ghosh and B. J. Marshall, Inorg. Chem., 1970, 9, 2512.

7. D. Davidson and L. A. Welo, J. Phys. Chem. 1928, 32, 1191.

8. K. Chandra, D. Raj and S. P. Puri, J. Chem. Phys. 1967, 46, 1466.

9. M. B. Robin, Inorg. Chem. 1962, 1, 337.

10. E. Fluck, W. Kerler and W. Neuwirth, Angew Chem. $1963,75,461$.

11. J. F. Duncan and P. W. R. Wigley, J. Chem. Soc. $1963,1020$.

12. S. C. Fung and H. G. Drickamer, J. Chem. Phys. 1969, 51, 4353.

13. A. Ito, M. Suenaga and K. Ono, J. Chem. Phys. 1968, 48, 3597.

14. N. Erickson and N. Elliot, J. Phys. Chem. Solids 1970, 31, 1195.

15. J. F. Allen and B. R. Edwards, J. Inorg. Nucl. Chem. $1973,35,3547$.

16. K. Maer, Jr., M. L. Beasley, R. L. Collins and W. O. Milligan, J. Am. Chem. Soc. 1968, 90, 3201.

17. D. Liebfritz and W. Bremser, Chemiker-Zeitung $1970,94,982$.

18. G. K. Wertheim and A. Rosenwaig, J. Chem. Phys. 1971, 54, 3235.

19. H. J. Buser, A. Ludi, P. Fischer, T. Studach and B. W. Dale, Z. Phys. Chem. 1974, 92, 354.

20. We will use Arabic numerals to indicate the charges on high spin ions and Roman numerals to indicate the charges on low spin ions throughout this paper.

21. H. J. Buser, D. Schwarzenbach, W. Petter and A. Ludi, Inorg. Chem. 1977, 16, 2704.

22. D. B. Brown, D. F. Shriver and L. H. Schwartz, Inorg. Chem. 1968, 7, 77.

D. B. Brown and D. F. Shriver, Inorg. Chem. 1969, 8, 37.

23. A. Ludi and H. U. Güdel, Helv. Chim. Acta. 1968, 51, 2006.

24. A. Ludi and H. U. Güdel Structure and Bonding, Vol. 14, Chap. 1. Springer-Verlag, Berlin (1973).

25. A. K. Bonnette and J. F. Allen, Inorg. Chem. 1971, 10, 1613.

26. H. J. Buser, Ph.D. Thesis. Universität Bern (1974).

27. B. N. Figgis and J. Lewis, Progress in Inorganic Chemistry, Vol. 6, Chap. 2. Interscience, New York (1964).

B. N. Figgis and J. Lewis, Techniques of Inorganic Chemistry, Vol. IV, Chap. 4. Interscience, New York (1965).

28. V. E. Simmons, Ph.D. Thesis. Boston University (1963).

29. T. H. Gould, Ph.D. Thesis. The University of Michigan (1974).

P. W. Merrithew, Ph.D. Thesis. The University of Michigan (1969).

30. W. R. Dunham, C. T. Wu, R. M. Polichar, R. H. 
Sands and L. J. Harding, Nucl. Inst. and Methods $1977,145,537$.

31. A. N. Garg and P. S. Geol, J. Inorg. Nucl. Chem. 1970, 32, 1547.

32. D. Hall, J. H. Slater, B. W. Fitzsimmons and K. Wade, J. Chem. Soc. A 1971, 800.

33. A. W. Chester and A. E. Schweizer, Inorg. Nucl. Chem. Lett. 1977, 7, 451.

34. U. Weihofen, Z. Naturforsch 1972, 274, 565.

35. M. Ruegg, A. Ludi and K. Ruder, Inorg. Chem. 1971, 10, 1773.
36. D. W. Smith, Inorg. Chem. 1966, 5, 2336.

37. F. Herren, P. Fischer, A. Ludi and W. Halg, Inorg. Chem. 1980, 19, 956.

38. W. Perkins and Y. Hazony, Phys. Rev. B 1972, 5, 7. G. K. Wertheim, D. N. E. Buchanen and H. J. Guggenheim, Phys. Rev. B 1970, 2, 1392.

39. J. F. Allen and B. R. Edwards, J. Inorg. Nucl. Chem. 1973, 35, 3547.

40. M. B. Robin and P. Day, Adv. Inorg. Chem. Radiochem. 1967, 10, 248. 